\title{
On correlation between urban development, land subsidence and flooding phenomena in Jakarta
}

\author{
H. Z. Abidin, H. Andreas, I. Gumilar, and I. R. R. Wibowo \\ Geodesy Research Group, Institute of Technology Bandung, Jl. Ganesha 10, Bandung, Indonesia \\ Correspondence to: H. Z. Abidin (hzabidin@gmail.com)
}

Received: 11 March 2015 - Accepted: 11 March 2015 - Published: 11 June 2015

\begin{abstract}
Jakarta is the capital city of Indonesia with a population of about 10.2 million people, inhabiting an area of about 660 square-km. It is located within a deltaic plain and passes by 13 natural and artificial rivers. In the last three decades, urban development of Jakarta has grown very rapidly in the sectors of industry, trade, transportation, real estate and many others, which has caused several negative environmental impacts. In turns Jakarta is then prone toward a few natural hazards mainly land subsidence and flooding. In general, based on geodetic measurement methods (e.g. Leveling, GPS surveys, and InSAR), conducted since 1982 up to 2014, it is obtained that land subsidence in Jakarta exhibits spatial and temporal variations, with the typical rates of about 3 to $10 \mathrm{~cm} \mathrm{year}^{-1}$. In general, the impacts of land subsidence in Jakarta can be seen in the forms of cracking of permanent constructions and roads, changes in river canal and drain flow systems, wider expansion of coastal and/or inland flooding areas, and malfunction of drainage system. Several areas along the coast of Jakarta already have experienced tidal flooding during high tide periods. These coastal flooding usually occurs in the areas with relatively large subsidence rates. Subsidence in the areas along the rivers which are flowing throughout Jakarta will also worsen the impacts of riverine flooding. The changes in river canal and drain flow systems and malfunction of drainage system due to land subsidence will also aggravate the flooding. Land subsidence will have direct and indirect affects with the flooding in Jakarta, both in coastal or inland areas.
\end{abstract}

\section{Introduction}

Land subsidence can geometrically defined as the downward displacement of the land surface relative to certain reference surface, such as mean sea level (MSL), geoid or reference ellipsoid. It is natural-anthropogenic hazard affecting quite many large urban areas (cities) in the world, including Jakarta, the capital city in Indonesia. Jakarta has a population of about 10.2 million people in 2013, inhabiting an area of about 660 square-km. It is located on the lowland area in the northern coast of West Java, centered at the coordinates of about $6^{\circ} 15^{\prime} \mathrm{S}$ and $+106^{\circ} 50^{\prime} \mathrm{E}$ (see Fig. 1). Topographically, the area of Jakarta has slopes ranging between 0 and $2^{\circ}$ in the northern and central parts, between 0 and $5^{\circ}$ in the southern part, and its southern-most area has an altitude of about $50 \mathrm{~m}$ above mean sea level. There are also 13 rivers flowing through Jakarta, which form the main drainage system of Jakarta. According to Rimbama and Suparan (1999), there are five main landforms of Jakarta, namely: alluvial land- forms (southern part), landforms of marine-origin (northern part adjacent to the coastline), beach ridge landforms (northwest and northeast parts), swamp and mangrove swamp landforms (coastal fringe), and former channels (perpendicular to the coastline).

As the megapolitan city, Jakarta has a very rapid urban development in the sectors of industry, trade, transportation, real estate, and many others (Firman, 1999, 2004; Hudalah et al., 2013). Several negative environmental problems have been introduced by this exponentially increased urban development (Firman and Dharmapatni, 1994; Hudalah and Firman, 2012), such as: extensive conversion of agricultural areas into residential and industrial areas, significant disturbance to ecological and hydrological functions of the upland of Jakarta area and river catchment areas, and increase in groundwater extraction due to development of industrial activities and the high population increase. These negative impacts will contribute to land subsidence phenomena in 


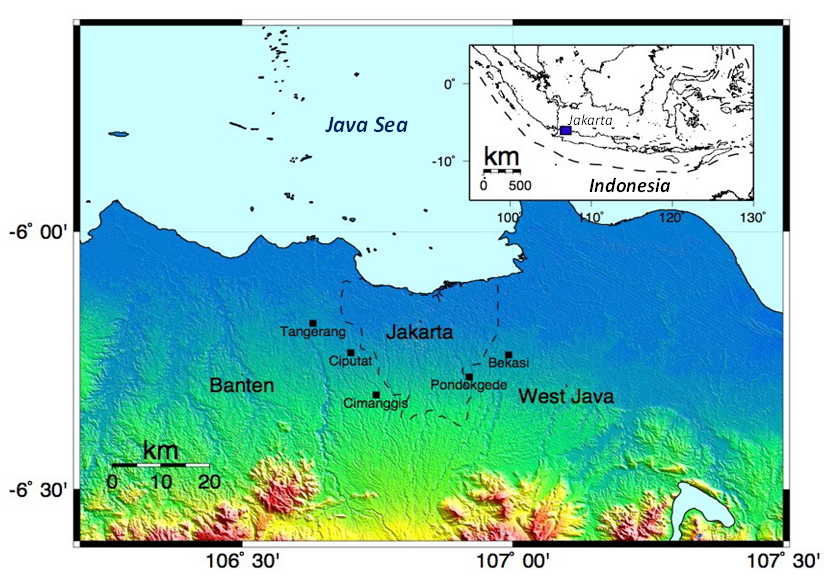

Figure 1. Location of Jakarta, the capital city of Indonesia.

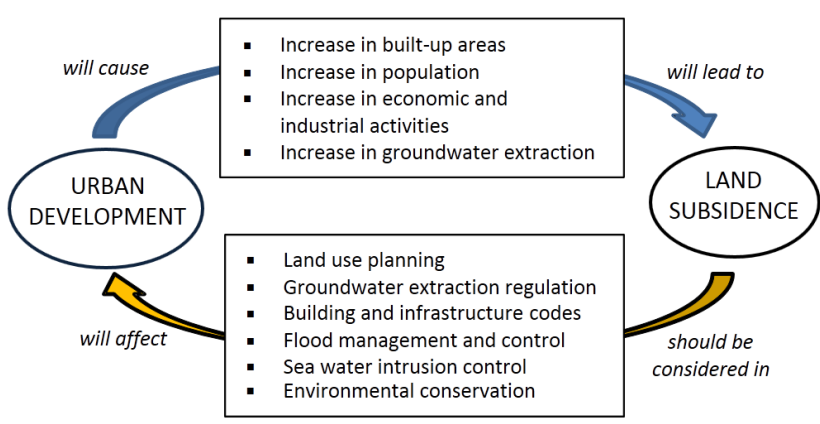

Figure 2. Urban development and land subsidence relation in Jakarta (Abidin et al., 2011).

several places in Jakarta, and the resulted land subsidence will also then affect the urban development plan and process (Abidin et al., 2011), as illustrated in Fig. 2.

Land subsidence in Jakarta has been observed using several geodetic techniques and has been widely reported for many years (Rismianto and Mak, 1993; Murdohardono and Sudarsono, 1998; Purnomo et al., 1999; Rajiyowiryono, 1999; Abidin et al., 2001, 2004, 2008, 2010, 2011, 2013; Koudogbo et al., 2012; $\mathrm{Ng}$ et al., 2012; Chaussard et al., 2013). According to those studies, land subsidence in Jakarta has spatial and temporal variations with typical rates of about 3 to $10 \mathrm{~cm}_{\text {year }}{ }^{-1}$. Several locations however, can have higher rates at certain time period and location.

Jakarta has historically experienced many flooding, especially during the rainy season, both riverine and coastal flooding (Caljouw and Nas, 2005; Texier, 2008; Hurford and Leito, 2010). Major flooding that have been reported was in 1654, 1699 (caused mainly by Salak volcano eruption), 1711, 1714, 1854, 1873, 1918, 1942, 1976, 1979, 1996, 2002, 2007, 2008, 2013, and 2014. Flooding in Jakarta is usually occured during the rainy season (December to February), and caused by several factors that are directly and indirectly working together. These natural, human and environmental factors of flooding are quite numerous, such as: high rainfall
Table 1. Observed land subsidence rates in Jakarta; after Abidin et al. $(2001,2011,2013)$. .

\begin{tabular}{|c|c|c|c|c|}
\hline \multirow[t]{2}{*}{ No. } & \multirow[t]{2}{*}{ Method } & \multicolumn{2}{|c|}{$\begin{array}{c}\text { Subsidence } \\
\text { Rates }\left(\mathrm{cm}^{-1} \text { year }^{-1}\right)\end{array}$} & \multirow[t]{2}{*}{$\begin{array}{r}\text { Observation } \\
\text { Period }\end{array}$} \\
\hline & & Min-Max & Typical & \\
\hline \multirow{2}{*}{1} & \multirow{2}{*}{ Leveling Surveys } & $1-9$ & $3-7$ & 1982-1991 \\
\hline & & $1-25$ & $3-10$ & 1991-1997 \\
\hline 2 & GPS Surveys & $1-28$ & $4-10$ & 1997-2011 \\
\hline 3 & InSAR & $1-12$ & $3-10$ & 2006-2010 \\
\hline
\end{tabular}

intensity (2000-4000 mm year $^{-1}$ ) during the rainy seasons; 13 rivers which are flowing to the sea through lowland topography; high tides and sea level rise; rapid urban development and population growth; uncontrolled land use changes and environmental degradation in the upstream areas and along the rivers; dense illegal settlements along the rivers; direct waste dumping into the rivers by the peoples; poor drainage and sewerage systems; and land subsidence phenomena.

Land subsidence in urban area should theoretically have spatial relation with flooding in certain location. This paper investigates the spatial correlation between land subsidence and flooding phenomena in Jakarta, although still in qualitative manner.

\section{Land Subsidence Characteristics in Jakarta}

Land subsidence rates in Jakarta has been estimated using several geodetic methods, such as Leveling, GPS survey, InSAR, Microgravity, and Geometric-Historic. In general, land subsidence in Jakarta has a spatial and temporal variation, with the typical rates between 3 to $10 \mathrm{~cm}_{\text {year }}{ }^{-1}$, as shown in Fig. 3 and Table 1. The observed subsidence rates along the coastal areas of Jakarta are relatively larger than the inland areas, although the rates along the coastal zone of Jakarta itself have spatial variation. The more detail characteristics of land subsidence in Jakarta can be seen in (Abidin et al., 2001, 2004, 2008, 2010, 2011, 2013; Ng et al., 2012, Chaussard et al., 2013).

Land subsidence in Jakarta can be caused by the combination of the following factors, namely: excessive groundwater extraction, natural consolidation of alluvium soil, load of infrastructures and constructions, and tectonic activities (Murdohardono and Sudarsono, 1998; Rismianto and Mak, 1993; Harsolumakso, 2001; Hutasoit, 2001). Considering the spatial variation of land subsidence rates in Jakarta area, then it can be expected that the contribution of each factor on the subsidence at each location also has spatial variation. Tectonic activities seem to be the least dominant factor, while excessive groundwater extraction is considered to be one of dominant factor for causing land subsidence in Jakarta.

The impacts of land subsidence in Jakarta can be seen in several forms, such as of cracking of building and infrastruc- 

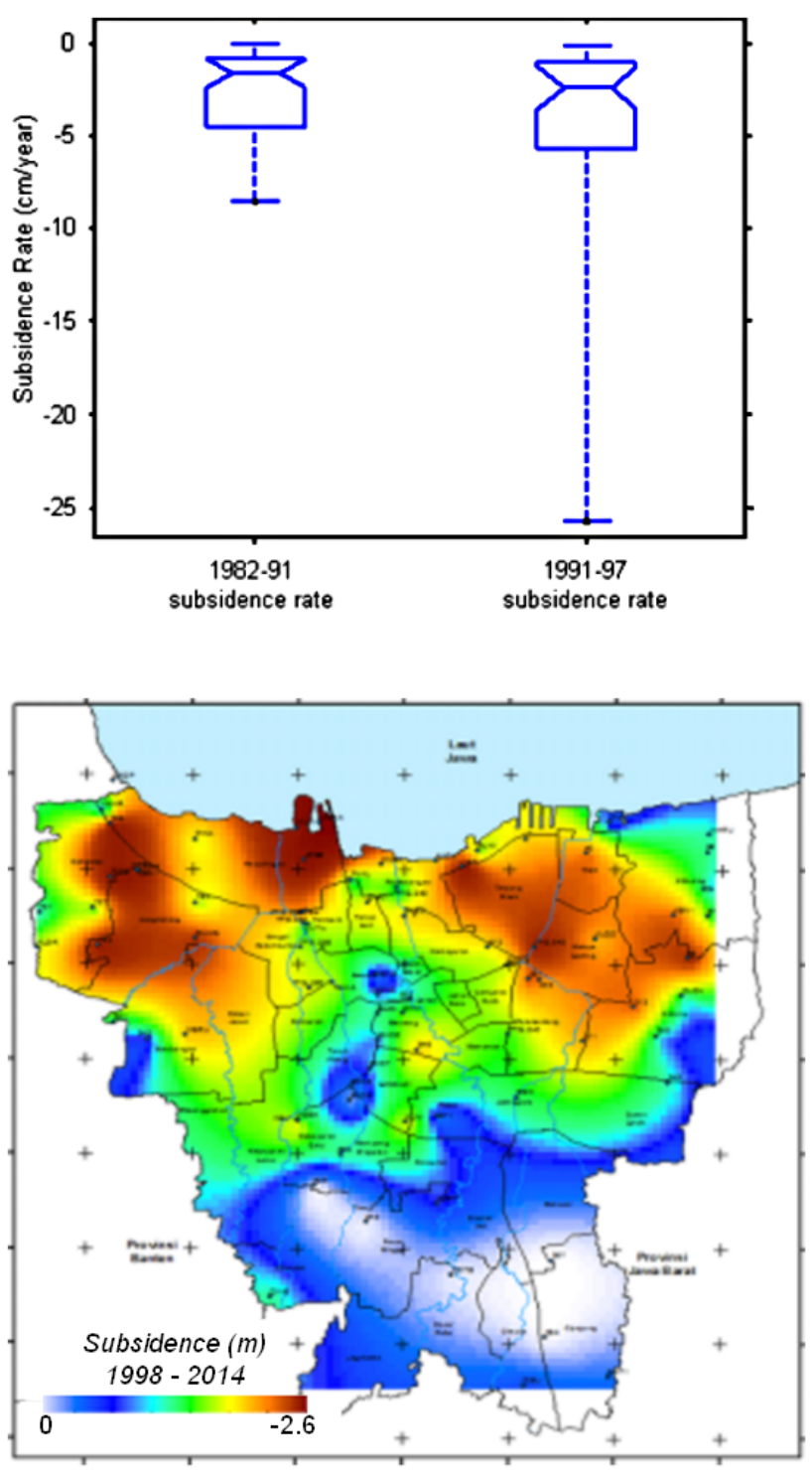

Figure 3. Temporal and spatial variations of land subsidence in Jakarta: (top) Box-and-Whisker plots of land subsidence rates as derived by leveling surveys from 1982 to 1997 (Abidin et al., 2011); (bottom) land subsidence magnitudes as derived by GPS surveys from 1998 to 2014 (Wibowo, 2014).

tures, "sinking" of houses and buildings, changes in river canal and drain flow systems, wider expansion of coastal and/or inland flooding areas, malfunction of drainage system, and increased inland sea water intrusion. In the coastal areas of Jakarta, which have relatively higher subsidence rates (Abidin et al., 2010, 2011), the collateral impact in the form of coastal flooding during high tides is even more damaging. This repeated coastal flooding not just deteriorates the function of building and infrastructures, but also badly influences the quality of living environment and life (e.g. health and sanitation condition) in the affected areas (Abidin et al., 2011). It is now accepted that potential losses due to land subsidence

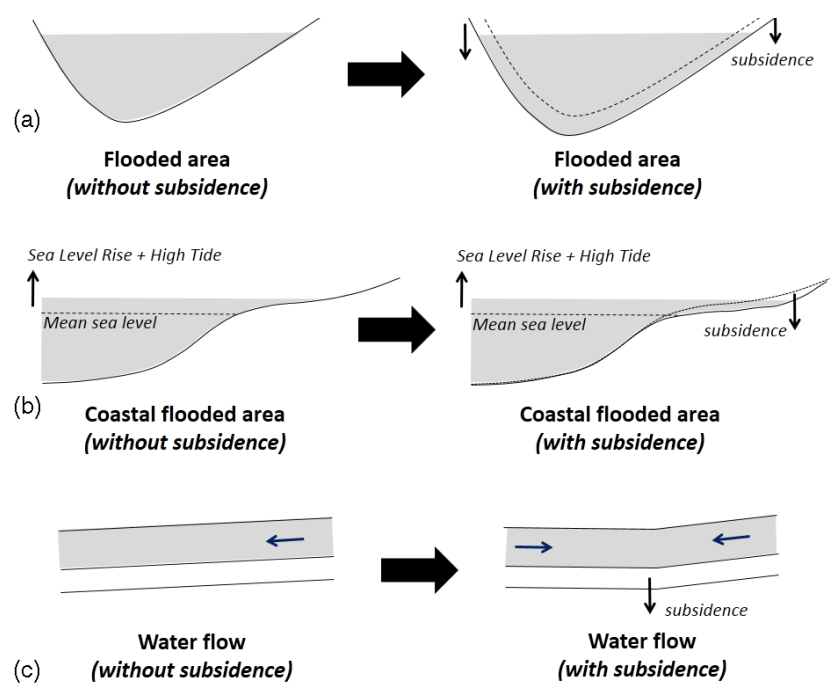

Figure 4. Impacts of land subsidence on flooding phenomena.

in Jakarta are actually quite significant (Ward et al., 2011; Viets, 2010). In this case, the development and maintenance costs of building and infrastructures in the affected areas are usually higher than the normal situation. The related social and environmental costs due to direct and indirect impacts of land subsidence are also significant.

\section{Impacts of Land Subsidence on Flooding Phenomena In Jakarta}

On-going land subsidence in several areas of Jakarta will have spatial relation with repeated flooding during the rainy seasons in certain areas. Land subsidence in flooding prone area will theoretically lead to expanded coverage and deeper water depth of flooded (inundated) areas, as illustrated in Fig. 4. In coastal areas affected by land subsidence, sea level rise and high tide will usually worsen the situation. Moreover, changes of water flow pattern in drainage, canal and river systems passing the subsidence area, may also affect flooding system in the respected area.

Since 2000 up to now, at least there are four major flooding in Jakarta, namely on 26 January-1 February 2002, 414 February 2007, 15-24 January 2013, and 15-27 January 2014. If the land subsidence affected areas as derived by Leveling, GPS and InSAR are compared with the flooded areas in Jakarta during the 2000, 2007 and 2013 major flooding (see Figs. 5 to 7), it can be realized that there are some spatial correlations between land subsidence and flooding affected areas. Several flooded areas are spatially coincided with the subsidence affected areas; while several flooded areas along the rivers do not show spatial correlation with subsidence phenomena. It should be noted in Fig. 6 that, the water depths in the flooded areas during 2007 flooding are also spatially coincided with magnitudes of land subsidence in the period 
(a)

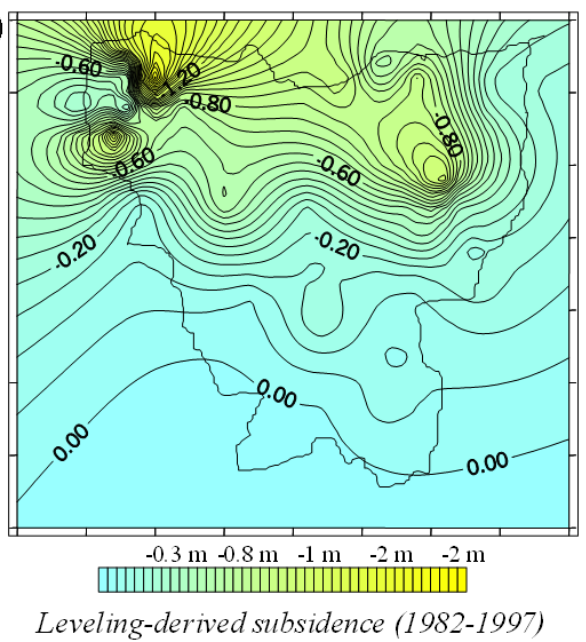

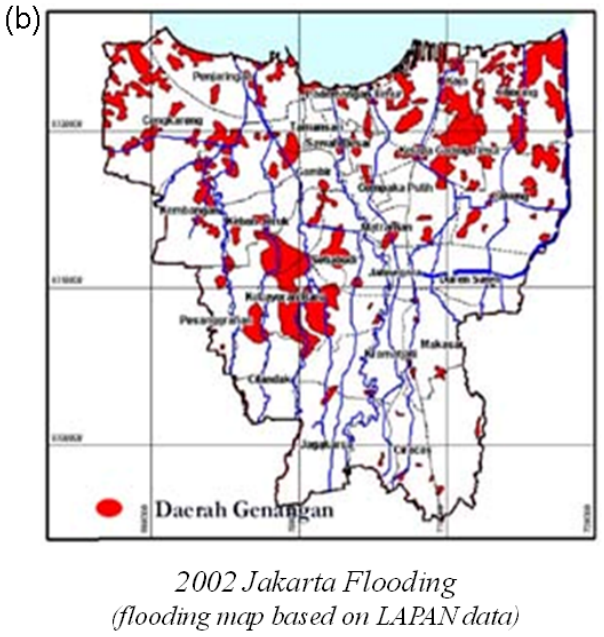

Figure 5. Spatial correlation between leveling-derived land subsidence (1982-1997) and flooding area in Jakarta (2002).

(a)

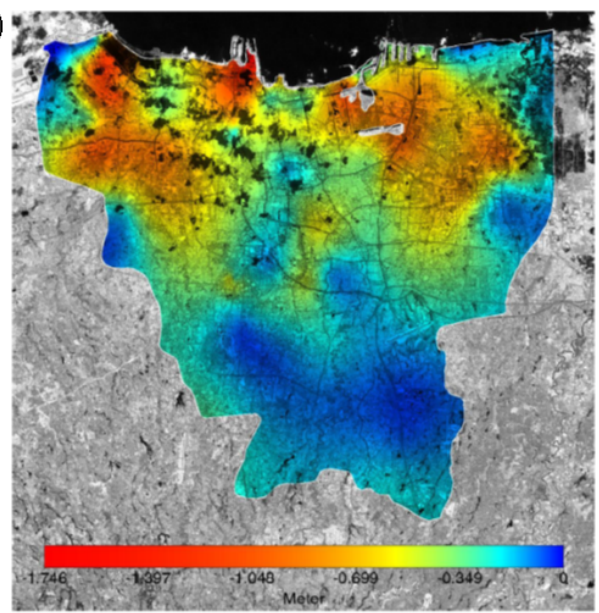

GPS-derived subsidence (2000-2011) (b)

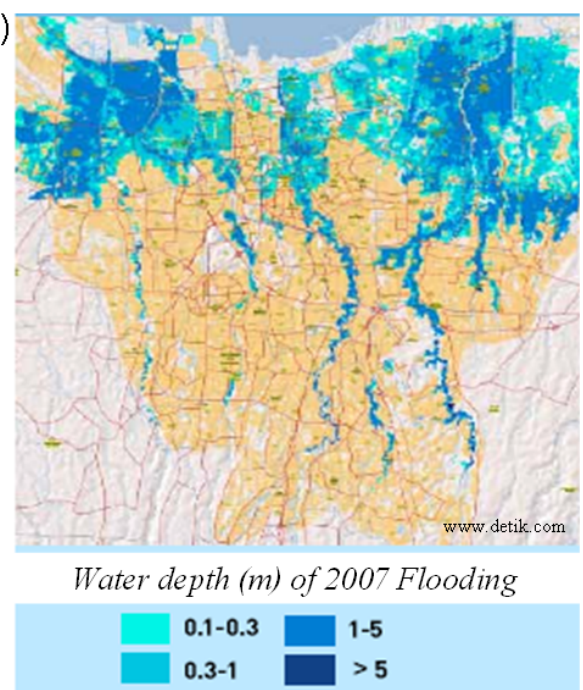

Figure 6. Spatial correlation between GPS-derived land subsidence (2000-2011) and flooding area in Jakarta (2007).

of 2000 to 2011. However, more quantitative picture of this correlation still needs to be elaborated and modeled.

\section{Closing remarks}

Although land subsidence phenomena in Jakarta has been studied since 1980s, the detail characteristics and mechanisms of land subsidence in Jakarta, both in spatial and temporal domains, are still not yet fully established. It is however understood that there is a strong linkage between land subsidence and urban development process in Jakarta. Land subsidence itself will theoretically have direct and indirect affects with the flooding in Jakarta, both in coastal or inland areas.

In general, from this study it can be concluded that qualitatively there is certain spatial correlation between land sub- sidences affected areas with flooded (inundated) areas in Jakarta. The exact mechanism of the two phenomena relation is however still not yet fully revealed; and more quantitative picture of this correlation still needs to be figured out. In this regard, several activities are required, such as: detail mapping of the spatial and temporal rates and impacts of land subsidence, detail mapping of flooded (inundated) area during the flooding events, and detail flood risk modelling for Jakarta.

In this detail flood risk modelling, the direct and indirect impacts of urban development and land subsidence, should be properly taken into account besides the prime movers factors of flooding in Jakarta as illustrated in Fig. 8. Research related to quantitative relation between land subsidence and flooding phenomena in Jakarta is now undergoing. 
(a)

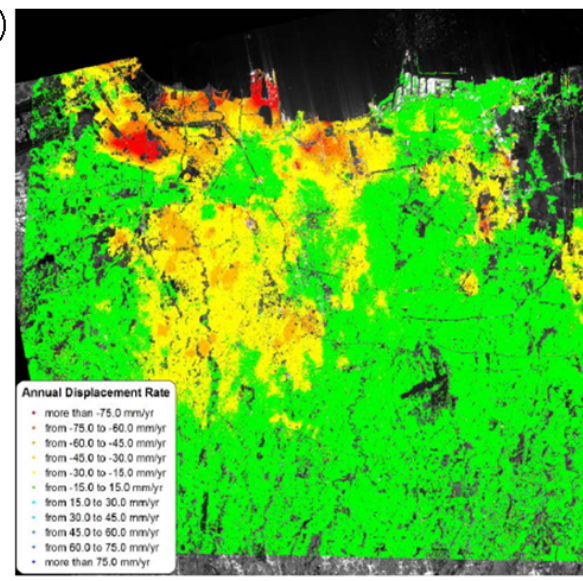

InSAR-derived subsidence (2007-2011)

(Koudogbo et al., 2012) (b)

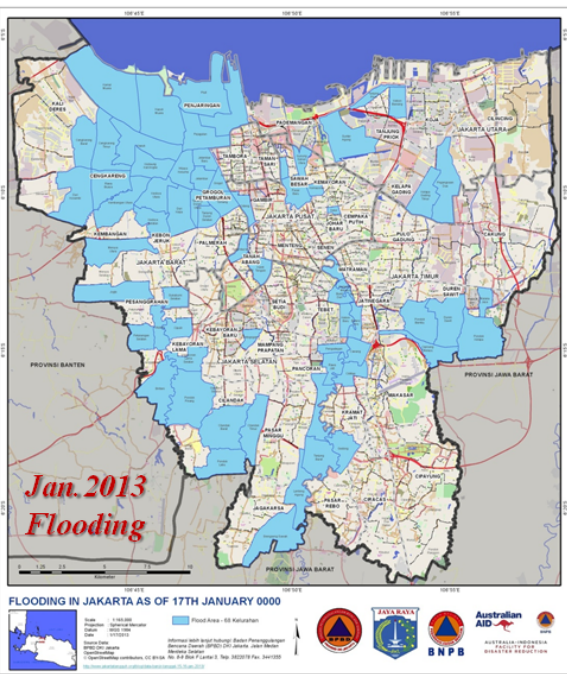

Figure 7. Spatial correlation between InSAR-derived land subsidence (2007-2011) and flooding area in Jakarta (2013).

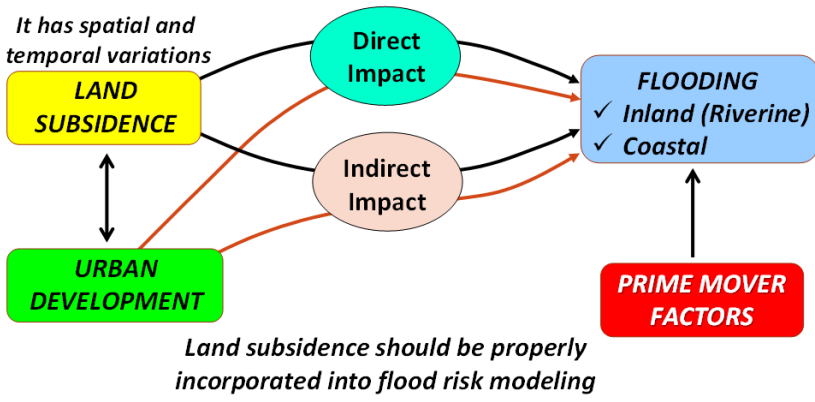

Figure 8. Flood risk modeling which incorporates land subsidence phenomena in Jakarta.

Acknowledgements. Land subsidence study in Jakarta has been conducted since 1997 using several research grants from Ministry of Science, Technology, and Higher Education of Indonesia, from the Provincial Government of Jakarta, and from ITB Research programs. The GPS surveys were conducted by the Geodesy Research Group of ITB, the Geospatial Agency of Indonesia, and the staffs and students from the Department of Geodesy and Geomatics Engineering of ITB.

\section{References}

Abidin, H. Z., Djaja, R., Darmawan, D., Hadi, S., Akbar, A., Rajiyowiryono, H., Sudibyo, Y., Meilano, I., Kusuma, M. A., Kahar, J., and Subarya, C.: Land Subsidence of Jakarta (Indonesia) and its Geodetic-Based Monitoring System, Natural Hazards, J. Int. Soc. Prevent. Mitig. Nat. Hazards, 23, 365-387, March, 2001.

Abidin, H. Z., Djaja, R., Andreas, H., Gamal, M., Hirose, K., and Maruyama, Y.: Capabilities and Constraints of Geodetic Techniques for Monitoring Land Subsidence in the Urban Areas of Indonesia, Geomatics Research Australia, 81, 45-58, December, 2004.
Abidin, H. Z., Andreas, H., Djaja, R., Darmawan, D., and Gamal, M.: Land subsidence characteristics of Jakarta between 1997 and 2005, as estimated using GPS surveys, GPS Solutions, Springer Berlin/Heidelberg, 12, 23-32, 2008.

Abidin, H. Z., Andreas, H., Gamal, M., Gumilar, I., Napitupulu, M., Fukuda, Y., Deguchi, T., Maruyama, Y., and Riawan, E.: Land Subsidence Characteristics of the Jakarta Basin (Indonesia) and its Relation with Groundwater Extraxtion and Sea Level Rise, in: Groundwater Response to Changing Climate, IAH Selected Papers on Hydrogeology No. 16, edited by: Taniguchi, M. and Holman, I. P., CRC Press, London, ISBN:978-0-415-54493-1, Chapter 10, 113-130, 2010.

Abidin, H. Z., Andreas, H., Gumilar, I., Fukuda, Y., Pohan, Y. E., and Deguchi, T.: Land subsidence of Jakarta (Indonesia) and its relation with urban development, Nat. Hazards, 59, 1753-1771, 2011.

Abidin, H. Z., Andreas, H., Gumilar, I., Sidiq, T. P., and Fukuda, Y.: On the Roles of Geospatial Information for Risk Assessment of Land Subsidence in Urban Areas of Indonesia, in: Intelligent Systems for Crisis Management, edited by: Zlatanova, S., Peters, R., Dilo, A., and Scholten, H., Lecture Notes in Geoinformation and Cartography, Springer-Verlag Berlin Heidelberg, 277-288, 2013.

Caljouw, M. and Nas, P. J.: Flooding in Jakarta: Towards a blue city with improved water management, Bijdragen tot de Taal-, Landen Volkenkunde, 454-484, 2005.

Chaussard, E., Amelung, F., Abidin, H. Z., and Hong, S.-H.: Sinking cities in Indonesia: ALOS PALSAR detects rapid subsidence due to groundwater and gas extraction, Remote Sensing of Environment, Elsevier, 128, 150-161, 2013.

Firman, T. and Dharmapatni, I. A. I.: The challenges to suistanaible development in Jakarta metropolitan region, Habitat Int., 18, 79 94, 1994

Firman, T.: From Global City to City of Crisis: Jakarta Metropolitan Region Under Economic Turmoil, Habitat Int., 23, 447-466, 1999. 
Firman, T.: New town development in Jakarta Metropolitan Region: a perspective of spatial segregation, Habitat Int., 28, 349-368, 2004.

Harsolumakso, A. H.: "Struktur Geologi dan Daerah Genangan", Buletin Geol., 33, 29-45, 2001.

Hudalah, D. and Firman, T.: Beyond property: Industrial estates and post-suburban transformation in Jakarta Metropolitan Region, Cities, 29, 40-48, 2012.

Hudalah, D., Viantari, D., Firman, T., and Woltjer, J.: Industrial land development and manufacturing deconcentration in Greater Jakarta, Urban Geogr., 34, 950-971, 2013.

Hutasoit, L. M.: "Kemungkinan Hubungan antara Kompaksi Alamiah Dengan Daerah Genangan Air di DKI Jakarta”, Buletin Geol., 33, 21-28, 2001.

Hurford, A. P. and Leito, J. P.: Urban pluvial flooding in Jakarta: applying state-of-the-art technology in a data scarce environment, Water Sci. Technol., 62, 2246-2255, 2010.

Koudogbo, F. N., Duro, J., Arnaud, A., Bally, P., Abidin, H. Z., and Andreas, H.: Combined X- and L-band PSI analyses for assessment of land subsidence in Jakarta, Proc. SPIE 8531, Remote Sensing for Agriculture, Ecosystems, and Hydrology XIV, 853107, 19 October 2012.

Murdohardono, D. and Sudarsono, U.: Land subsidence monitoring system in Jakarta, Proceedings of Symposium on JapanIndonesia IDNDR Project: Volcanology, Tectonics, Flood and Sediment Hazards, Bandung, 21-23 September, 243-256, 1998.

Ng, A. H., Ge, L., Li, X., Abidin, H. Z., Andreas, H., and Zhang, K.: Mapping land subsidence in Jakarta, Indonesia using persistent scatterer interferometry (PSI) technique with ALOS PALSAR, Int. J. Appl. Earth Observ. Geoinform., 18, 232-242, August, 2012.
Purnomo, H., Murdohardono, D., and Pindratno, H.: Land Subsidence Study in Jakarta, Proceedings of Indonesian Association of Geologists, Volume IV : Development in Engineering, Environment, and Numerical Geology, Jakarta, 30 November-1 December, 53-72, 1999.

Rajiyowiryono, H.: Groundwater and Landsubsidence Monitoring along the North Coastal Plain of Java Island, CCOP Newsletter, 24, 19, July-September, 1999.

Rimbaman, R. and Suparan, P.: Geomorphology, in: Coastplan Jakarta Bay Project, Coastal Environmental Geology of the Jakarta Reclamation Project and Adjacent Areas, CCOP COASTPLAN Case Study Report No. 2., Jakarta/Bangkok, 21$25,1999$.

Rismianto, D. and Mak, W.: Environmental aspects of groundwater extraction in DKI Jakarta: Changing views, Proceedings of the 22nd Annual Convention of the Indonesian Association of Geologists, Bandung, 6-9 December, 327-345, 1993.

Texier, P.: Floods in Jakarta: when the extreme reveals daily structural constraints and mismanagement, Disaster Prevent. Manage., 17, 358-372, 2008.

Viets, V. F.: Environmental and Economic Effects of Subsidence, Publication of Lawrence Berkeley National Laboratory, LBNL Paper LBL-8615, Permalink: http://escholarship.org/uc/ item/1sb4c8vh, 251 pp., 2010.

Ward, P. J., Marfai, M. A., Yulianto, F., Hizbaron, D. R., and Aerts, J. C. J. H.: Coastal inundation and damage exposure estimation: a case study for Jakarta, Nat. Hazards, 56, 899-916, 2011.

Wibowo, I. R. R.: Correlation Analysis between Land Subsidence znd Flooding, Case Study of Jakarta (in Indonesian), Undergraduate Final Report, Department of Geodesy and Geomatics Engineering, Institute of Technology Bandung, 77 pp., 2014. 